\title{
RELIGIOUS CULTURE DEVELOPMENT IN COMMUNITY SCHOOL: A CASE STUDY OF BOYOLALI MIDDLE SCHOOL, CENTRAL JAVA, INDONESIA
}

\author{
Meti Fatimah ${ }^{1 *}$, Sutama $^{2}$, Abdullah $\mathrm{Aly}^{3}$ \\ ${ }^{1}$ Doctor Candidate, Universitas Muhammadiyah Surakarta, Indonesia, ${ }^{2}$ Department of Teacher Training and Education, \\ Universitas Muhammadiyah Surakarta, Indonesia, ${ }^{3}$ Department of Islamic Education, Universitas Muhammadiyah \\ Surakarta, Indonesia. \\ Email: ${ }^{1 *}$ fatimahcan@gmail.com, ${ }^{2}$ sutama@ usms.ac.id, ${ }^{3}$ aa130@ums.ac.id
}

Article History: Received on $07^{\text {th }}$ November 2019, Revised on $15^{\text {th }}$ March 2020, Published on $03^{\text {rd }}$ April 2020

\begin{abstract}
Purpose: This study aims to explore the religious culture development in the community school for public junior high schools in Boyolali, Indonesia.

Methodology: This research employs a qualitative approach with interviews and observation as its main research tools for data collection. Three schools participated in this study. Namely: SMP Negeri 4 Boyolali, SMP Negeri 2 Boyolali, and SMP Negeri 6 Boyolali.

Findings: This research reveals three main themes for developing a religious culture in the school community; firstly creating a systematic model of school policy; secondly, building cooperation with school leaders and citizens; and lastly, developing a religious culture through extracurricular activities.

Implications of the study: The results of this study may be useful for the government in Indonesia as a reference in the development of religious culture in schools or may be useful for the development of religious cultural education in an area.

Novelty: Student backgrounds greatly influence religious behavior, as well as school policies, which will also influence the development of religious culture, so the development of religious culture will affect the growth of student character.

This study creates a systematic school policy model, builds cooperation between school leaders and citizens, and develops a religious culture through extracurricular activities in the school community, to be further enhanced by good management and clear regulations. The 2003 National Education System Law states that the first and foremost criteria in the formulation of these goals are people who believe in and fear of God Almighty and have good character. For religious culture to be applied in educational institutions, the importance of religion, cultural education needs to be developed.
\end{abstract}

Keywords: Development, Religious Culture, School Community, Strategy.

\section{INTRODUCTION}

Education practitioner reports the development of relations between the Catholic Education Commission, Victoria, Australia and the Theology Faculty at Leuven Catholic University, Belgium. It is found that there is a lot of interest in the religious education curriculum which emphasizes dialogue, embraces religious plurality and introduces active questions in a moment of dialogue (Luby, 2019). Westernization of science has raised doubts and conjectures to the stage of scientific methodology, the westernization of science has also made doubts as a legitimate epistemological tool in science. The development of Western civilization science rejects revelation (religion) as a science, so science is only limited from the sources of the five senses (empirical) and reason, rational (Paryono, 2018). Outside of revelation, we know nothing about God. It can be said that all Barth's theology in time pivots on the insight that "at the beginning of all knowledge of God is not human self-recognition but the knowledge of God himself, humans are known by God, namely revelation (Herskowitz et al., 2019).

Based on the exploration of Islamic education that the implementation of Islamic religious education which is realized in building a religious culture at various levels of education especially junior high school education levels is important to be implemented. The importance of religion for students is seen in the philosophical view of education as stipulated in the 2003 National Education System Law that national education aims to develop the potential of students to become human beings who have faith and are devoted to God Almighty, noble, healthy, knowledgeable, capable, creative, independent, and become citizens who are democratic and responsible (Tim Diknas RI, 2003).

In the Indonesian national education, Islamic religious education is compulsory for all levels of formal education. Considering such a position, Islamic religious education has the potential to be strategic in responding to several major problems in religious life (Arifin, 2016). The role of Islamic education is not only to build character but also to build the nation. Islamic religious education is expected to have a stake in building the nation's character and participating in actualizing promises of independence. The purpose of Islamic education in Indonesia is not only to create religious people but also to make good citizens (Abdallah, 2016). Islamic education is taught to the community, especially in schools with a vision to create people who fear Allah (Mulyasa \& Aryani, 2017). 
Seen from the perspective of implementation perspective, the development of religious culture is very important for schools, bearing in mind the current era, where the current of globalization and liberalization is increasingly swift influencing the concepts of the faith and morality of all Muslims, especially young people who are still attending high school first. The number of adolescent behaviors that deviate in the community while religious education in the school is running, then research is needed to be analyzed to find the right formulation to answer the existing problems and research that has been done has not optimally answered the problem. Then the researchers tried to reveal and analyze the problem of developing a religious culture in schools.

\section{LITERATURE REVIEW}

Education in Indonesia provides opportunities for citizens to receive education and also provides opportunities for improving the quality of education so that citizens in Indonesia have quality education and can compete. In the field of school management, the school community should develop school management, one of which is developing a religious culture. The inculcation of religious values is the responsibility of parents and schools (Muhaimim, 2001). Parents play an important role in influencing a child to adopt the character of Islamic life (Sokip et al., 2019). Religiosity is more directed towards the appreciation of the quality and attitude of one's life based on religious values that become beliefs (Amalia et al., 2015).

Manifesting religious culture in schools is an effort to internalize religious values into students. In addition, it shows the function of the school as an institution that functions to transmit culture (Latif, 2005). Islamic education curriculum management from planning, implementation to evaluation has been directed and designed to realize the religious culture in schools (Mulyasa \& Aryani, 2017). Religious culture attempts to internalize religious values because it is an urgent need for educational institutions, especially secondary education to become independent education using activities through religious culture (Fathurrohman, 2016). School religious culture is a way of thinking and acting for school members based on religious values (religiousness). Religious according to Islam is to carry out religious teachings as a whole (Sahlan, 2010).

Four foundations can be used as a reference for the school community in implementing religious culture in schools:

First, in the religious foundation that the creation of religious culture is carried out at school solely because it is a development of the human potential that exists from birth or nature. As stated in Q.S. Ar-Ruum: 30 states "Then face your face straight to religion (Allah); (stay on top) the nature of God who has created humans according to that nature. There is no change in the nature of God. (That is) right religion; but most humans do not know." The verse explains that basically the child has brought religious nature, and then depends on the educators in developing the nature itself by the age of the child in his growth.

Second, in the constitutional basis of Chapter X UUSPN article 36 paragraph 3, it is stated that the curriculum is prepared by the level of education within the framework of the Unitary Republic of Indonesia (NKRI) with due regard to the increase in faith and piety and the increase in noble morals (Tim Diknas RI, 2003).

Third, the philosophical foundation explains that when viewed in the aspect of purpose, the objectives of Islamic education are: a) prepare someone from the religious side, namely by teaching religious verses according to the Qur'an and the Hadith of the Prophet because, in that way, the potential of faith is strengthened, as with other potentials that if we are ingrained, then it seems as if he becomes fire; b) prepares someone in terms of morals; c) prepare someone in terms of social or social; d) prepares someone in vocational or occupational terms; e) prepare someone in terms of thinking, because with thought someone can hold a variety of jobs or certain skills: f) prepare someone in terms of art, here including music, poetry, art development and others (Chotimah \& Fathurrahman, 2014).

Fourth: the historical foundation is taken from the historicity of the entry of PAI in schools because the religious culture is the development of Islamic religious education in schools. When the Sjahrir government approved the establishment of the Ministry of Religion on January 3, 1946, the Muslim elite placed the educational agenda as one of the main agenda of the Ministry of Religion.

The Muslim elite carried out two main efforts: First, developing religious education (Islam) in public schools which since the proclamation has been under the guidance of the Ministry of PPK. These efforts include: a) fight for the status of religious education in public schools and higher education; b) developing a religious curriculum; c) prepare qualified religious teachers; d) prepare religious textbooks. Second, improving the quality or modernization of educational institutions which have been giving attention to Islamic religious education and modern general knowledge at the same time. The strategy is: a) by renewing the existing curriculum and strengthening the portion of the modern public teaching curriculum so that it does not lag behind public schools; b) develop the quality and quantity of teachers in general studies; c) provide learning facilities, such as general study books; d) establishing schools of the ministries of religion in various regions as a model.

From the historical explanation above, it can be understood that one of the struggles of the Indonesian Muslim elite at the beginning of independence was to strengthen the position of Islamic religious education in public schools to universities. Therefore, in today's globalization era, practitioners of Islamic education should improve the quality of Islamic religious education by creating and developing a religious culture in schools (Fathurrohman, 2015). Developing 
the Islamic religion is not enough just to develop the teaching of Islam in the classroom, namely in the form of giving additional time to teach. Furthermore, the development strategy must use a cultural approach by applying religious material as a school culture; this in particular, throughout the development of educational leadership, the awareness of both the community and the school community to shape religious culture in schools (Sahlan, 2014).

To develop religious values in educational institutions requires a strategy, among them is through a) strategy, namely the strategy of religious education institutionalization by using power or through people's power, in this case, the role of the head of an educational institution with all its power is very dominant in making a change;b) persuasion strategy, which is carried out through the formation of opinions and views of the community or citizens of educational institutions;c) normative reductive. Norms are rules that apply in the community. Norms of socialization through education norms are coupled with re-education to install and replace the paradigm of thinking of old institutions with new ones (Fathurrohman, 2015). To realize religious culture in educational institutions, efforts to develop a religious culture are at three levels, namely: a) the level of values adopted; b) the level of daily practice; c) the level of cultural symbols (Koentjaraningrat, 2006).

Based on the idea that the purpose of Islamic religious education is to purify the soul, shape morals, prepare someone in terms of religion, and even from a human being who is, then further development is needed in learning Islamic religious education to touch on the affective and psychomotor aspects through the creation of religious culture in schools, because the average religious education, learning in schools is based only on the cognitive aspects and does not pay much attention to the affective and psychomotor aspects.

\section{METHODOLOGY}

\section{Research Design}

Data collection was carried out using observation, interviews, and documentation. The researchers played the role of the main instruments. This research was conducted in Boyolali, Central Java, Indonesia. Boyolali sub-district has a junior high school from SMPN 1 to SMPN 6, which has the same characteristics that are both public schools and have students with different religious backgrounds, namely Islam and Christianity. The number of students who are Muslim is more than the number of students who are Christians. Three schools participated in this study, namely: SMPN 4 Boyolali, SMPN 2 Boyolali, and SMPN 6 Boyolali.

\section{Data and Sources of Data}

Data sources are classified into three groups: informants, documents, and evidence of places. In qualitative research, data sources are also divided into two groups, namely primary and secondary data. Primary data were obtained directly from the school in Boyolali, Central Java, which was the place of research, while secondary data had been obtained by other parties. The roles and functions of the two data are complementary and supportive. Data collection techniques are a combination of various data collection methods and in this case, include (a) interviews (b) observations and (c) documentation.

\section{Data-Analysis Techniques}

Data analysis is a process of organizing data into patterns, categories, and one basic description so that it can be found and formulated to work hypotheses. Several stages will be carried out. First, there will be a reduction in data covering selection, categorization, and sorting. Second, data exploration is carried out to clarify and deepen the data found. Third, the data is verified to prove the accuracy of the truth of existing data, by one way to crosscheck with other data.

\section{RESULTS AND DISCUSSION}

\section{Creating Systematic School Policies}

The development of religious culture in schools is one of the parts that must be achieved by the school management, considering that in the current era where globalization and liberalization currents are increasingly swift influencing the concepts of faith and morality of society, especially the young generation, and student morals that must be guarded against various Possible influences, one of which is the highly advanced social media communication. In the 2003 National Education System Law that the first and foremost criteria in the formulation of these objectives are people who believe in and fear God Almighty and have good character.

This formula shows our education system prioritizes religion than science. So that religious culture should be applied in educational institutions, there are strong indications in the law that show the importance of religious cultural education needs to be developed. Moral education must be based on the concept of Islam and placing morals in science is a shared responsibility because it includes the doctrinal implications that the purpose of human life must be within the framework of worshiping God (Fatimah, 2018). There are many legal opportunities for school communities to develop and implement this education. However, there are still schools that have not managed the development of religious culture with good and directed management. 
The policy is a written rule that is a formal organizational decision that is binding and regulates behavior with the aim of creating a new value system. Tri Joko, the principle of SMP Negeri 4 Boyolali, stated that developing a religious culture in the school community is by creating systematic school policies. The need for policies taken from schools so that religious, cultural development programs run well, according to management that has been arranged. The policy that is implemented should not be detrimental to all school members, because not all SMP students in Boyolali are Muslim students but some are non-Muslim. Both Muslim and non-Muslim students must participate in activities that have been jointly designed in order to contribute to developing a religious culture in schools, one of these policies is by establishing Islamic religious sessions, religious Friday activities, Dhuha prayers and Dhuha prayers, and muraja'ah al-Qur'an. Meanwhile, non-Muslim students' activities are adjusted to the deepening of their religious activities and are also scheduled at the school. Various policies are directed to develop a religious culture in schools, of course, the implementation of religious culture as a form of learning of Islamic Religious Education (PAI).

According to (Tarman 2015), students are a major component of the education system, students' views and behavior must be studied to have a clear effect on the reform. Various policies implemented in schools in order to develop a religious culture solely to achieve school identity so that it becomes the priority of outside audiences that schools with a general education background are also able to create and develop a well-structured Islamic culture without any pressure from anywhere. Because actually state schools have the right to develop school management in order to develop a good school culture, the development of religious culture, literacy, culture or another culture that can elevate a school to become a school of achievement and make that culture a school identity. And always remember that developing a religious culture in the school community is not only the responsibility of the school, but the government must also pay attention to the development of religion for students in the school, the government not only spawned a law but also contributed to its development. The important role of local governments in responding to education development planning initiated by the central government to achieve quality education. Furthermore, capacity building is proposed as a solution to promote a responsive local government (Dewi et al., 2018).

Aside from schools and the government, the most important thing in terms of developing religious culture is parenting; the concept of family education needs to be reiterated, because the family is the first and most important institution for a student, that is, children today who live in an ever-changing era. In addition, the development of this religious atmosphere is an effort to condition the school atmosphere with religious values and behavior. To develop a religious atmosphere can be done with the process of a) leadership, b) the scenario of creating a religious atmosphere, c) a vehicle for worship or a place of worship, d) community support (Sahlan, 2010). Furthermore, economic status, the environment, and good parental learning facilities increase student independence in learning mathematics based on lessons (Sutama et al, 2017). So in broad outline that the economic status, environment, and good parental learning facilities will also increase the independence of students from any field of science including growing religiosity in students.

\section{Building Cooperation between School Leaders and Residents}

Principals and teachers need to systematically set standards regarding the implementation and stages of the application of religious culture in schools. So that the success of the development of religious culture can be evaluated. The principal is understood to be an important factor in improving the conditions of teaching and learning in schools; however, relatively little is known about leadership strategies where principals must dedicate their time and efforts to improve results (Liebowitz \& Porter, 2019). Religious education is an expression given to education relating to religious studies. This can be referred to as teachings achieved through churches or religious associations for information regarding doctrinal beliefs and faiths, or for studying in various fields of religion (Abumere, 2013). Freedom of religion and not being established are separate principles and that the application of these principles leads to a neutral public field. Although it looks fair, it is secular, or not "really" neutral. Conversely, non-establishment leads to a public field where non-religion dominates religion in political discourse (Deagon, 2018). Developing religious culture in schools aims to instill the values of Islamic religion obtained by students from the learning outcomes at school to be applied in everyday student behavior. To get the results that are expected, collaboration among school leaders, teachers, students, and all school members is needed.

The development of religious culture is inseparable from the mutual agreement of all school members in formulating agreed religious values that need to be developed in schools and subsequently establishing joint responsibility for those values. The development of religious culture in schools is part of the habit of applying religious values in life at school and in society. A strategy to build cooperation between schools, students, parents and the environment around religious experiences needs to be improved so that it provides motivation and participates in religious-cultural activities. Jenson reports that positive psychology has an important role in the education process. It aims to develop motivation and confidence among students, as well as help them to be optimistic and flexible in their studies and show their creativity in various fields. It also helps teachers to develop strong relationships with their students, which positively influence both parties, improving their psychological health (Shawaqfeh \& Almahaireh, 2019).

In a modern context, efforts to educate children are essential in a stable and creative environment for Muslim families. Therefore, building cooperation with parents is very important for schools as information so that policies implemented in schools related to religious culture can be well received by all school members. Harmonious cooperation must be 
maintained and maintained which is manifested in a) mutual understanding, not to dominate each other; b) there is mutual acceptance, not to walk with each other according to their own volition; c) mutual trust, not to be suspicious of each other; d) respect for each other, not to claim each other the truth; e) mutual love, not to hate one another and be jealous (Muhaimin, 2003).

\section{Enhancing Religious Culture by Maximizing the Role of Religious Education}

Between 1974 and 1990, at least 30 countries made the transition to democracy, almost double the number of democratic governments in the world. Is this democratization part of an ongoing and growing "global democratic revolution" that will reach almost every country in the world (Huntington, 1991), and this affects the people who run religious education as the foundation of education? Education and religion are inseparable aspects of every society. Education is the backbone of development (Opoku et al, 2015) mentality of a nation's society.

Education is understood as training or shaping. In this study, this implies the art of learning, the process of gaining knowledge. In an effort to advance school education to improve religious behavior through education, it has become important to explain the task of religion in the development of education. Religion in education provides the formation of character and moral significance: Character is the cream of life and, as such, must be the goal of all forms of education. Educators must emphasize character building in education. The formation of character or moral education is related to all human behavior. Education services must contain their policy framework explaining their first objective to provide a framework for the development of standards, core values and ethics (moral) for the teaching profession to make them make a very large contribution to the improvement of students' religious behavior, character-building must be an objective every form of education.

Valuable knowledge or information: Educators who possess knowledge or the significance of information from education justify their stand with strong arguments. They argue that knowledge is indispensable for all right actions and is the source of all power. This is the knowledge that makes a realist a successful visionary in any profession. Cultural education is undoubtedly the most important thing aimed at producing culture. One's spiritual development must be the highest educational goal and prioritize spiritual values in education.

In Indonesia, the involvement of religious groups or religious organizations in education has contributed to the spiritual development of both teachers and students. Some educators have emphasized the need for comprehensive educational goals. This viewpoint has led to the development of two complete life goals and harmonious development goals which suggest spiritual and physical development. Islam intends to be a universal message for mankind, suitable for every person and every age. The resulting tension, which is by no means unique, manifests itself in many areas of Islamic law and history, as in the case studied here. Although people can try to live according to religious dogma, they will always interpret it in a socially and culturally specific way (El-Fadl, 1994).

We need to accept that the main goal of Islam is the formation of moral and character education that can develop people, both men, and women, with a clean soul, a strong will, the right ideals, and a high level of morality. So the need for cooperation between schools and parents of students, because through this collaboration, both the principal, teachers, teachers of religious education can provide their suggestions. The internalization of Islam, the spiritualization of education, the Islamization of knowledge, the Syariah curriculum, and the salad (ancestral) curriculum. Such icons, then, influence the implementation of the idea of educational integration. Furthermore, the community provides a positive response and support for school performance (Santoso et al, 2019).

Is the role of schools to teach and maintain faith, or should the aim of religion in schools be to increase awareness and understanding? This is an important issue in an increasingly pluralistic global society and any discussion on religious education must take into account the potential danger when religious bodies appear to have an interest in school control and, in particular, from the curriculum. This is the view of this writer. That religion does have a valid place in education and that religious values can be a positive and a formative influence on the quality of education. However, this must not sacrifice educational freedom and freedom of thought and choice. Religious organizations must stand well from the impression that they want to use education only to control or manipulate society. Most importantly, they must recognize the need for inclusion, respect, and justice for all - not least for minorities and those who consider there is no religion. In the world with a diverse, it is important to uphold certain human and religious values as a basis for understanding and peace. These values include, inter alia, freedom, respect, and reciprocity of justice, which is his right to receive justice in his teaching.

\section{Developing Religious Culture Through Extracurricular}

Strengthening the main values in Character Strengthening Education (PPK) is also possible through extracurricular activities. Extracurricular activities are educational activities outside of class hours to help the development of students according to their needs, potential, talents, and interests. Given the limited time spent studying Islamic religious education in public schools which are only 3 hours a week, the school community added time allocation for the development of religious education lessons through the development of religious culture. Sustainable professional development (CPD) programs are the core of such a strategic approach that provides educators with essential knowledge 
and skills to deal with issues related to diversity, achieve equality and increase student participation (Awang-Hashim et $\underline{\mathrm{al}, 2019)}$.

Schools have a very big role to develop a religious culture with the aim of preparing students even deeper to draw closer to God, study Islamic education correctly and overall, of course, the future mission is to create a generation of Muslims who fear Allah and have good morals so that they will get graduates who are both intelligent and have good character. According to Islamic educators are responsible for developing students by achieving their full potential, whether it is their affective, cognitive, or psychomotor potential (Tafsir, 1994).

Religious extracurricular activity is an activity to develop a religious culture in schools that is of great benefit to all school members. Islamic religious education, learning in developing religious culture, that the activity is packaged through prayer activities in congregation / Friday prayers at school, holiday ceremonies, Osis/rohis activities, social services, Islamic breathing arts and various other religious social activities carried out outside of class time (Shaleh, 2005). Values education in Indonesian primary school activities (intra-curricular, extracurricular, school culture development, and collaboration with the community) tend to use an approach Values education in Indonesian primary school activities (intra-curricular, extracurricular, school culture development, and collaboration with the community) tend to use the value transmission approach through training methods, modeling, conditioning, and habituation, which fosters moral behavior in the form of discipline and student's adherence to rules and norms (Hakam, 2018).

The implementation of extracurricular activities is an overall part of the development of school institutions, extracurricular activities rely more on the initiative of the school. In a juridical manner, extracurricular implementation has a strong legal basis, because it is regulated in a ministerial decree which must be implemented by the school. One of the ministerial decrees governing extracurricular activities is the decision of the Minister of National Education RI No. 125 / U / 2002 concerning the educational calendar and the amount of effective learning in school. In the appendix section of the Minister of Education's decision on July 31, 2002. School or Madras holidays during the month of Ramadan are filled and utilized to carry out various activities directed at increasing moral character, understanding, understanding and moral practice(Mulyana, 2004).

According to researchers that extracurricular activities are students in the coaching and responsibility of schools located at school or outside of school, with scheduled provisions or at a time in order to enrich, improve and expand student knowledge, develop values or positive attitudes and further apply knowledge students have learned in core courses or elective courses. To be carried out effectively, extracurricular activities need to be prepared in a mature regulation and balanced with cooperation between schools, students and parents. But in reality, in schools, there is more enthusiasm in developing scientific activities in general, while activities related to the religious development of school students seem to not care. Though it is very important that the two sciences are integrated so that students can achieve both.

\section{CONCLUSION}

The development of religious culture is influenced by the background of students and school policies that are applied so that it impacts on the character of students. The need for policies taken from schools so that religious, cultural development programs run well, according to management that has been arranged. Students must follow activities that have been designed together in the context of developing a religious culture in schools. By implementing a good religious culture in the school will get the behavior of religious school people, positive thinking, the growth of good manners and the creation of a conducive learning atmosphere.

\section{LIMITATION AND STUDY FORWARD}

This research only revealed a small number of problems related to the development of religious culture. Many factors that influence the process of developing a religious culture have not been revealed in this study. For this reason, it is recommended that subsequent researchers conduct further studies.

\section{ACKNOWLEDGMENT}

We thank the management of Boyolali 4 Public Middle School, Boyolali 2 Public Middle School, Boyolali Public Middle School 6 Middle Java, Indonesia for accepting us to conduct research on religious culture in schools.

\section{REFERENCES}

1. Abdallah. (2016). Exclusivism And Radicalism In Schools: State Policy And Educational Politics Revisited. Indonesian Journal For Islamic Studies, 23(3), 625. https://doi.org/10.15408/sdi.v23i3.4425

2. Abumere, F. I. (2013). The Significance Of Religious Education In Local Primary Schools (Specific Reference To Christianity). OSR Journal Of Humanities And Social Science, (6)6, 69-94. https://doi.org/10.9790/08370666994

3. Amaliah, I., Aspiranti, T., \& Purnamasari, P. (2015). The Impact Of The Values Of Islamic Religiosity On Islamic Job Satisfaction In Tasikmalaya West Java, Indonesia, Industrial Centre. Procedia Social Behavioral Sciences, 211, 984-991. https://doi.org/10.1016/j.sbspro.2015.11.131 
4. Arifin, S. (2016). Islamic Religious Education And Radicalism In Indonesia: Strategy Of De-Radicalization Through Strengthening The Living Values Education. Indonesian Journal Of Islam And Muslim Societies, 6(1), 93-126. https://doi.org/10.18326/ijims.v6i1.93-126

5. Awang-Hashim, R., Kaur, A., \& Valdez, N. P. (2019). Strategizing inclusivity in teaching diverse learners in higher education. Malaysian Journal of Learning and Instruction, 16(1), 105-128.

6. Chotimah, C. \& Fathurrohman, M. (2014). Komplemen Manajemen Pendidikan Islam Konsep Integratif Pelengkap Manajemen Pendidikan Islam. Yogyakarta: Teras. p346.

7. Deagon, A. (2018). Liberal Secularism And Religious Freedom In The Public Space: Reforming Political Discourse. Harvard Journal Of Law \& Public Policy, 41(3), 902-934.

8. Dewi, M. P., Rahmatunnisa, M., Sumaryana, A. \& Kristiadi. JB. (2018). Ensuring Service Quality in Education for Indonesia's Sustainable Education. Journal of Social Studies Education Research, 9(4), 65-81.

9. El Fadl, K. A. (1994). Islamic Law And Muslim Minorities:The Juristic Discourse On Muslim Minorities From The Second/Eighth To The Eleventh/Seventeenth Centuries.Islamic Law and Society,1(2),141-187, https://doi.org/10.2307/3399332

10. Fathurrohman, M. (2015). Budaya Religius dalam Peningkatan Mutu Pendidikan: Tinjauan Teoritik dan Praktik Kontekstualisasi Pendidikan Agama Islam di Sekolah. Yokyakarta: Kalimedia. p88-89. https://doi.org/10.21274/taalum.2016.4.1.19-42

11. Fathurrohman, M. (2016). Pengembangan Budaya Religius dalam Meningkatkan Mutu Pendidikan. Jurnal Pendidikan Islam Ta'allum, 4(1), 19-42. https://doi.org/10.21274/taalum.2016.4.1.19-42

12. Fatimah, Meti. (2018). Concept Of Islamic Education Curriculum: A Study On Moral Education In Muhammadiyah Boarding School, Klaten. Jurnal Didaktika Religia, 6(2), 103. https://doi.org/10.30762/didaktika.v6i2.1103

13. Hakam, K. A. (2018). Tradition of Value Education Implementation in Indonesian Primary Schools. Journal of Social Studies Education Research, 9(4), 295-318.

14. Herskowitz, D., Rosenzweig, F., Barth, K. (2019). A Chapter In The Jewish Receptionof Dialectical Theology. The Journal Of Religion, 80.http://www.journals.uchicago.edu/t-and-c.

15. Huntington, S. P. (1991). Democracy's Third Wafe, Journal of Democracy, 2(2), Spring, 12. https://doi.org/10.1353/jod.1991.0016

16. Koentjaraningrat. (2006). "Kebudayaan, Mentalitas dan Pembangunan” dalam Muhaimin. Nuansa Baru Pendidikan Islam. Jakarta: Raja Grafindo Persada. p157.

17. Latif, A. (2005). Pendidikan Berbasis Nilai Kemasyarakatan. Bandung: Refika Aditama. p30.

18. Liebowitz, D. D.,\& Porter, L. (2019). The Effect of Principal Behaviors on Student, Teacher, And School Outcomes: A Systematic Review and Meta-Analysis of The Empirical Literatur, Review of Educational Research. https://doi.org/10.3102/0034654319866133

19. Luby, Antony. (2019). Dialogic Skills In Re: Recontextualising The Dialogue School. Journal of religious education, 67(2), 127-142. https://doi.org/10.1007/s40839-019-00079-1

20. Muhaimin. (2003). Arah Baru Pengembangan Pendidikan Islam: Pemberdayaan, Pengembangan Kurikulum Hingga Redefinisis Islamisasi Pengetahuan.Cet. 1. Bandung: Nuansa. p22.

21. Muhaimin. (2009). Rekonstruksi Pendidikan Islam dari Paradigma Pengembangan, Manajemen Kelembagaan, Kurikulum Hingga Strategi Pembelajaran. Jakarta: Rajawali Pers. p328.

22. Mulyana, R. (2004). Mengartikulasikan Pendidikan Nilai. Bandung: Alfabeta. p212.

23. Mulyasa, H.E. \& Aryani, W. D. (2017).Developing Religious Culture In School.The International Journal Of Scientific \& Te Chnology Research, 6(7), 263.

24. Naim, N. (2012). Character Building Optimalisasi Peran Pendidikan dalam Pengembangan Ilmu dan Pembentukan Karakter Bangsa. Yogyakarta: Ar-Ruz Media. p124.

25. Opoku, J. K., Manu, E. \& Wiafe, F. (2015). Religion, Education And Development In Ghana: A Historical Perspective, Global Journal Of Arts, Humanities And Social Sciences 3(12), 6-18.

26. Paryono. (2018). Pondasi Hukum peradaban Barat : pengaruh terhadap pengaturan serta penguasaan sumber daya alam dan energi, Dalam Pemikiran hukum profetik: Ragam paradigma menuju hukum berketuhanan.Yogyakarta: Ruas Media. p141.

27. Sahlan, A. (2010). Mewujudkan Budaya Religius di Sekolah: Upaya Mengembangkan PAI dan Teori ke Aksi. Malang: UIN Maliki Press. p75.

28. Sahlan, A. (2010). Mewujudkan Budaya Religius di Sekolah: Upaya Mengembangkan PAI dan Teori ke Aksi. Malang: UIN Maliki Press. p129.

29. Sahlan, A. (2014). Enhancement of Culture in Education: Research on Indonesian High School. ProcediaSocial and Behavioral Sciences, 143, 117-121. https://doi.org/10.1016/j.sbspro.2014.07.371

30. Santoso, M. A. F., Thoyibi, M., \& Aly, A. (2019). Integration Of Education:The Case Study Of Islamic Elementary Schools In Surakarta, Indonesia. Humanities \& Social Sciences Reviews, 7(4), 2019, pp 1046-1052. https://doi.org/10.18510/hssr.2019.74143

31. Shaleh, A. R. (2005). Pendidikan Agama \& Pembangunan Watak Bangsa. Jakarta: PT Raja Grafindo Persada. p170. 
32. Shawaqfeh, B., \& Almahaireh, A. (2019). TechnoWellness and Its Relationship with Happiness and Optimism Among University of Jordan Students. Journal of Social Studies Education Research, 10 (2), 145-167.

33. Sokip., Akhyak., Soim., Tanzeh, A.hmad \& Kojin. (2019). Character Building in Islamic Society: A Case Study of Muslim Families in Tulungagung, East Java, Indonesia. Journal of Social Studies Education Research, 10(2), 224-242.

34. Sutama., Narimo, S., \& Sari., D. P. (2017). The Impact of Independency in Lesson Study Based Mathematic Learning in Junior High School. International Journal Of Science And Applied Science: Conference Series, 2(1), 387. https://doi.org/10.20961/ijsascs.v2i1.16752

35. Tafsir, A. (1994). Ilmu Pendidikan dalam Prespektif Islam. Bandung: Remaja Rosdakarya. p72.

36. Tarman, B., Baytak, A., \& Duman, H. (2015). Teachers' Views on an ICT Reform in Education for Social Justice. Eurasia Journal of Mathematics, Science \& Technology Education, 11(4), 865-874. https://doi.org/10.12973/eurasia.2015.1445a

37. Tim Diknas RI. (2003). UU No. 20 Tahun 2003 Pasal 3 Tentang Sisdiknas. Semarang: Pustaka Ofset. p6. 